\title{
ZNACZENIE MIĘDZYNARODOWEGO PRAWA HUMANITARNEGO W ZWALCZANIU POWSTANIA W ŚWIETLE WYBRANYCH POPULACJOCENTRYCZNYCH DOKTRYN PRZECIWPOWSTAŃCZYCH
}

\section{Wstęp}

Militarne zaangażowanie Sojuszu Północnoatlantyckiego w Afganistanie oraz wsparcie udzielone rządowi tego państwa przez członków NATO w ramach misji ISAF udowodniły, iż odłożona do lamusa koncepcja zwalczania powstania (counterinsurgency, COIN) ${ }^{1} \mathrm{w}$ rzeczywistości jest niezbędna do skutecznego prowadzenia operacji wojskowych przeciw zbrojnym aktorom niepaństwowym. Członkowie Sojuszu zrezygnowali jednak z klasycznej strategii przeciwpowstańczej, nastawionej na likwidację wroga (w świetle której najlepszym sposobem na zdławienie powstania jest zabicie lub schwytanie członków sił przeciwnika w ramach tradycyjnych operacji wojskowych), na rzecz tzw. populacjocentrycznej

* Dr, Uniwersytet Jagielloński; e-mail: martigen@tlen.pl

1 Autor niniejszego artykułu zdecydował się na konsekwentne stosowanie jednolitej terminologii, dlatego w artykule występują wyłącznie takie pojęcia, jak "powstanie", „powstańcy” i „operacje/działania/doktryny przeciwpowstańcze”, choć w polskiej literaturze przedmiotu pojęcia te stosowane są zamiennie $\mathrm{z}$ takimi terminami, jak „rebelia/ rebelianci” "partyzantka/partyzanci” (mimo pewnych różnic semantycznych) oraz odpowiednio - „operacje/działania/doktryny przeciwrebelianckie” i „operacje/działania/ doktryny przeciwpartyzanckie" (zob. np. B. Kruszyński, Udziat sił zbrojnych USA w konfliktach w Iraku i Afganistanie - największych wojnach przełomu XX/XXI wieku, Poznań 2011; M. Madej, Czy w tym tunelu jest światto? Operacja ISAF na tle klasycznych koncepcji zwalczania partyzantki, [w:] W. Sokała, B. Zapała (red.), Asymetria i hybrydowość - stare armie wobec nowych konfliktów, Warszawa 2011; M. Marszałek, Operacje reagowania kryzysowego NATO. Istota. Uwarunkowania. Planowanie, Warszawa 2013; W. Więcek (red.), Działania przeciwrebelianckie w operacjach, Warszawa 2011). 
strategii zwalczania powstania, polegającej na „,zdobywaniu serc i umysłów” (,winning hearts and minds”) lub „zdobywaniu poparcia ludności” (,win the population”). Zdobycie i utrzymanie tego poparcia stanowi „nadrzędny imperatyw operacyjny" oraz ostateczny cel wszystkich podejmowanych działań. Zadaniem sił przeciwpowstańczych w tego rodzaju operacjach jest zdobycie społecznego poparcia poprzez ochronę ludności cywilnej, ustanowienie rządów prawa i stabilizację gospodarki. Zakres operacji COIN obejmujący działania militarne, polityczne i ekonomiczne może zagwarantować rządowi zdobycie zaufania i wsparcia ludności, a jednocześnie spowodować utratę poparcia dla powstania i w efekcie jego stłumienie. Zgodnie bowiem z założeniami populacjocentrycznej strategii przeciwpowstańczej, powstańców można pokonać jedynie wówczas, gdy ludność cywilna się od nich odwróci i przestanie udzielać im pomocy².

Niezwykle istotną rolę w realizacji celów operacji COIN pełni ścisłe przestrzeganie obowiązującego prawa, w tym zasad i norm międzynarodowego prawa humanitarnego $(\mathrm{MPH})^{3}$. Operacje COIN prowadzone są bowiem w sytuacji konfliktu zbrojnego, do którego MPH znajduje zastosowanie, a siły przeciwpowstańcze są zaangażowane w działania zbrojne ${ }^{4}$. Warto podkreślić, że $\mathrm{w}$ trakcie wspomnianych operacji niektóre z norm MPH mogą podlegać takiej interpretacji, by - nie naruszając ich istoty - mogły spełniać założenia strategiczne i operacyjne „zdobywania serc i umysłów", choć czasem może się to okazać trudnym zadaniem. Tytułem przykładu, prawo okupacji wojennej zabrania wprowadzania zmian politycznych i społecznych na terytorium okupowanym. Tymczasem cel operacji przeciwpowstańczych, jakim jest zdobycie przychylności ludności, wymaga różnorodnych działań służących odbudowie państwa oraz wprowadzania szeregu reform poprawiających sytuację jego mieszkańców, w tym takich, które mogą np. zmienić strukturę administracyjną kra-

2 Zob. G. Sitaraman, The Counterinsurgent's Constitution: Law in the Age of Small Wars, Oxford 2013, s. 5.

3 Zaznaczyć należy, iż pojawiające się w niniejszym artykule terminy „międzynarodowe prawo humanitarne", "prawo konfliktów zbrojnych” i "prawo wojny” są synonimicznymi określeniami dziedziny prawa międzynarodowego, regulującej zarówno postępowanie stron wojujących w zakresie prowadzenia działań zbrojnych, jak i ochronę osób niebiorących udziału w działaniach zbrojnych lub wyłączonych z walki (hors de combat) oraz ochronę dóbr i obiektów, które nie stanowią celu wojskowego.

${ }_{4}$ Zob. P. Łubiński, Próba oceny wybranych aspektów polskiego zaangażowania w ramach misji ISAF w Afganistanie, [w:] M. Kun-Buczko, M. Przybysz (red.), Bezpieczeństwo w dobie globalizacji. Prawo i praktyka, Białystok 2011, s. 354. 
ju. Powstańcy mogą być w świetle MPH dozwolonym celem ataku z wykorzystaniem broni śmiercionośnej, jednak potrzeba budowy zaufania do lokalnego rządu i wspierania jego władzy może prowadzić do wniosku, że lepiej jest użyć broni nieśmiercionośnej (zwanej też obezwładniającą), co może znacznie ograniczyć straty w życiu ludzkim. Kłopot w tym, że niektóre rodzaje tej broni są w świetle MPH zakazane ${ }^{5}$.

Rozwiązaniem powyższych dylematów może być ścisłe powiązanie strategii przeciwpowstańczej i prawa humanitarnego. W przypadku operacji przeciwpowstańczych o charakterze populacjocentrycznym jest to szczególnie ważne, ponieważ w operacjach tych środkiem ciężkości jest ludność cywilna, której ochrona jest przecież jednym z fundamentów $\mathrm{MPH}^{6}$. Populacjocentryczna strategia zwalczania powstania przypisuje zatem prawu humanitarnemu priorytetowe znaczenie $\mathrm{w}$ osiaganiu celów operacji wojskowych. Doktryny militarne (wojskowe) ${ }^{7}$, które w kompleksowy sposób ujmują wszelkie zagadnienia związane ze zwalczaniem powstania, również powinny uwzględniać szczególną rolę MPH w działaniach sił przeciwpowstańczych. W praktyce jednak doktryny te mogą się różnić choćby stopniem szczegółowości prezentowanych zobowiązań w zakresie MPH, liczbą odwołań do konkretnych uregulowań tego prawa czy interpretacją określonych zasad i norm. Celem niniejszego artykułu jest wykazanie, że w przypadku doktryn militarnych reprezentujących populacjocentryczne podejście do zwalczania powstania, prawo humanitarne zawsze odgrywa istotną rolę $\mathrm{w}$ prowadzeniu operacji przeciwpowstańczych, a postępowanie zgodne z zasadami i normami MPH ma ogromne znaczenie dla powodzenia tych operacji, począwszy od szczebla strategicznego, a skończywszy na taktycznym. Dlatego analizie poddano trzy konkretne doktryny przeciwpowstańcze (doktryny COIN), akceptu-

${ }^{5}$ Zob. W. Banks, Introduction - Shaping a Global Legal Framework for Counterinsurgency: Placing Postmodern War in Context, [w:] W. Banks (red.), Counterinsurgency Law: New Directions in Asymmetric Warfare, Oxford 2013, s. xvii; G. Sitaraman, The Counterinsurgent's, s. 44.

${ }^{6}$ G. Sitaraman, The Counterinsurgent's, s. 44.

7 Według J. Solarza, pojęcie to określa „zbiór zasad, którymi siły zbrojne kierują się w działaniach, prowadząc swoje operacje (...). Doktryny militarne zawierają podstawowe normy postępowania i ogólne procedury pozwalające na maksymalne skoordynowanie działań tworzących je formacji" (J. Solarz, Doktryny militarne XX wieku, Kraków 2009, s. 505). Autor ten zaznacza, że doktryny „różnią się od teorii naukowych brakiem pełnego uzasadnienia całości przyjmowanych przesłanek i wyprowadzanych z nich wniosków. Opierają się na określonym światopoglądzie, a czasem nawet na doświadczeniach i autorytecie tworzących je ludzi, którzy dają w ten sposób wyraz własnym przekonaniom" (tamże). 
jące wspomniany model populacjocentryczny - doktrynę brytyjska, amerykańską i Sojuszu Północnoatlantyckiego. Doktryny te przyjęto w formie podręczników wojskowych oraz instrukcji operacyjno-taktycznej i są to odpowiednio:

- brytyjski wojskowy podręcznik polowy dla działań związanych ze zwalczaniem powstania z 2009 r. - British Army Field Manual - Countering Insurgency;

- amerykański podręcznik polowy dotyczący powstań i sposobów ich zwalczania z 2014 r. - Field Manual (FM) 3-24/MCWP 3-33.5 Insurgencies and Countering Insurgencies ${ }^{9}$;

- instrukcja operacyjno-taktyczna NATO z 2011 r., określana jako doktryna sojuszniczych działań połączonych dla zwalczania powstania - AJP-3.4.4 Allied Joint Doctrine for Counterinsurgency $(\mathrm{COIN})^{10}$.

\section{Doktryna brytyjska z 2009 r.}

Spośród wszystkich państw, które w przeciągu ostatnich dwustu lat musiały zmierzyć się z powstaniami (tak na własnym tery torium, jak i poza jego granicami), Wielka Brytania ma zdecydowanie największe doświadczenie. Brytyjczycy zaczęli gromadzić to doświadczenie już kilkadziesiąt lat przed wybuchem II wojny światowej, podczas wojen prowadzonych w ich koloniach ${ }^{11}$. W okresie przed 1939 r. brytyjska armia zdecydowanie podzielała imperialny pogląd na zwalczanie powstań - należało uporać się z nimi szybko, w sposób stanowczy i bezwzględny. W erze postkolonialnej podejście Wielkiej Brytanii do operacji przeciwpowstańczych zaczęło ewoluować i dopasowywać się do nowej sytuacji (w dużej mierze pod wpływem działań w Irlandii Północnej). W rezultacie wypracowa-

${ }^{8}$ British Army Field Manual, Volume 1 Part 10 - Countering Insurgency, Army Code 71876, October 2009 [dalej: AFM Countering Insurgency].

${ }^{9}$ U.S. Army Field Manual (FM) 3-24/ Marine Corps Warfighting Publication (MCWP) 3-33.5 - Insurgencies and Countering Insurgencies, Headquarters Department of the Army, May 2014 [dalej: FM 3-24/MCWP 3-33.5].

${ }_{10}$ AJP-3.4.4 Allied Joint Doctrine for Counterinsurgency (COIN), North Atlantic Treaty Organization, February 2011 [dalej: AJP-3.4.4].

${ }_{11}$ Zob. A.J. Joes, Guerrilla Warfare: A Historical, Biographical, and Bibliographical Sourcebook, Westport-London 1996, s. 183. 
no trzy fundamentalne zasady leżące $u$ podstaw tych operacji: minimum siły, współpraca cywilno-wojskowa oraz elastyczność w sferze taktyki ${ }^{12}$. Zasady te nadal są istotnymi elementami nowych, współczesnych form operacji przeciwpowstańczych ${ }^{13}$.

Przyjęta w formie podręcznika polowego dla brytyjskiej armii doktryna przeciwpowstańcza z 2009 r. określa sposób planowania i prowadzenia operacji typu COIN na poziomie taktycznym. Zwrócono w niej uwagę, że $\mathrm{w}$ tego rodzaju operacjach należy skoncentrować wysiłki na zapewnieniu bezpieczeństwa miejscowej ludności oraz zdobyciu i utrzymaniu ich poparcia $^{14}$. Jest to zadanie, które stoi przed państwem przyjmującym, jego siłami bezpieczeństwa, armią brytyjską i ich sojusznikami. Autorzy doktryny objaśniaja, dlaczego nie jest to zwykłe militarne przedsięwzięcie, lecz pojedynek woli politycznej. Skuteczne zapewnienie bezpieczeństwa to "proces skomplikowany, niebezpieczny i krwawy”, wymagający czasu i poddający próbie rozwiązania przyjmowane przez wszystkie zaangażowane w ten proces strony. Doktryna dostarcza dowódcom na szczeblu taktycznym podstaw do planowania i prowadzenia operacji COIN i wymaga od nich wykorzystania ich doświadczenia i wiedzy w celu opracowania właściwego podejścia do konkretnych okoliczności. Nie jest to kompletny podręcznik na temat powstań i ich zwalczania, nie odnosi się też do konkretnego teatru działań czy grupy powstańczej - omawia tylko

12 G. Bulloch, Case Study 1: The Development of Doctrine for Countering Insurgency. The British Experience, [w:] AFM Countering Insurgency, p. 26, s. CS 1-6. T.R. Mockaitis zamiast elastyczności taktycznej używa sformułowania "decentralizacja systemu dowodzenia i kierowania" (T.R. Mockaitis, The Phoenix of Counterinsurgency, "The Journal of Conflict Studies" 2007, vol. 27, No. 1, s. 13).

${ }_{13}$ G. Bulloch, Case Study 1, p. 26, s. CS 1-6. Szerzej na temat historii brytyjskich operacji przeciwpowstańczych zob. m.in. M. Crawshaw, The Evolution of British COIN, https:// www.gov.uk/government/uploads/system/uploads/attachment_data/file/43334/jdp340theevolutionofbritishcoinbymichaelcrawshaw.pdf [dostęp: 18.09.2015 r.]; P. Dixon, "Hearts and Minds"? British Counter-Insurgency from Malaya to Iraq, "The Journal of Strategic Studies" 2009, vol. 32, No. 3; A. Jackson, British Counterinsurgency in History: A Useful Precedent?, „British Army Review” 2006, vol. 139; T.R. Mockaitis, The Phoenix; H. Strachan, British Counterinsurgency from Malaya to Iraq, „Royal United Services Institute Journal” 2007, vol. 152, No. 6.

${ }^{14}$ Według definicji zamieszczonej w brytyjskim podręczniku, zwalczanie powstania to „działania wojskowe, porządkowe, polityczne, ekonomiczne, psychologiczne i obywatelskie podejmowane $\mathrm{w}$ celu stłumienia rebelii, przy jednoczesnym zmierzeniu się $\mathrm{z}$ jej źródłami, wymagające wieloaspektowego podejścia obejmującego wymiar polityczny, ekonomiczny, społeczny, kulturowy i dotyczący bezpieczeństwa" (AFM Countering Insurgency, p. 1-11). 
kluczowe zagadnienia, które wynikają z doświadczeń ostatnich lat i odzwierciedla obecną sytuację $e^{15}$.

W brytyjskim podręczniku COIN z 2009 r. bardzo wyraźnie podkreślono obowiązek działania w zgodzie z prawem, czyniąc $\mathrm{z}$ tego obowiązku jedną z dziesięciu podstawowych zasad operacji COIN ${ }^{16}$. Wskazano, iż działanie poza prawem zawsze jest bezproduktywne i zawsze podważa, niekiedy nawet drastycznie, wiarygodność sił przeciwpowstańczych oraz rządów zaangażowanych $\mathrm{w}$ daną operację ${ }^{17}$. Ponadto konsekwencje zarzucanych lub popełnionych przestępstw mają ogromny wpływ na prowadzenie kampanii oraz, w sensie ogólnym, na reputację i nastawienie do Wielkiej Brytanii. Wystarczy wspomnieć negatywne dla procesu pokojowego w Irlandii Północnej konsekwencje „Krwawej Niedzieli”, 30 stycznia 1972 r. w Londonderry (w wyniku akcji oddziałów brytyjskich zginęło wówczas 13 osób), czy negatywne implikacje dla wizerunku sił brytyjskich w Iraku, gdy żołnierze brytyjskiego kontyngentu w 2003 i na początku 2004 r. bezprawnie pozbawili życia irackich cywili. Obszary związane z przestrzeganiem prawa, wymagające szczególnej analizy oraz wyraźnych wytycznych i odpowiedniego szkolenia, obejmują m.in. użycie siły, prowadzenie przeszukania oraz procedurę zatrzymania i przetrzymywania osób pozbawionych wolności ${ }^{18}$.

Jeśli chodzi o szczegółowe postanowienia dotyczące obowiązku przestrzegania MPH w operacjach COIN, zawarto je w rozdziale 12, odnoszącym się do prawnych aspektów zwalczania powstania. Zgodnie z tymi postanowieniami, bez względu na zadania i funkcje oddziałów brytyjskich, powinny one zawsze działać w ramach prawa wewnętrznego Wielkiej Brytanii oraz w zgodzie ze znajdującym zastosowanie prawem międzynarodowym wiążącym to państwo. Przykładowo, międzynarodowe prawo konfliktów zbrojnych stosuje się w przypadku konfliktu zbrojnego (tak międzynarodowego, jak i niemiędzynarodowego), nie obejmuje ono jednak swoim zakresem obowiązywania wewnętrznych zamieszek i nie-

${ }_{15}$ AFM Countering Insurgency - Foreword, s. i.

16 Zob. AFM Countering Insurgency, p. 1-2.

17 Tamże, p. 3-30. Dodać należy, iż omawiana doktryna zakłada, że rząd Wielkiej Brytanii będzie wykorzystywał Brytyjskie Siły Zbrojne oraz inne instrumenty władzy w celu prowadzenia dowolnych operacji wojskowych, by wspierać prawnie uznane państwo w przywróceniu i utrzymaniu prawa i porządku, dobrym sprawowaniu rządów (good governance) oraz, jeśli to konieczne, podstawowych usług, jakie tradycyjnie świadczy państwo (tamże, p. 1-12).

18 Tamże, p. 3-32. 
pokojów ${ }^{19}$. Wpływ na operacje prowadzone przez Wielką Brytanię, na jej terytorium i poza jej granicami, mają również prawa człowieka, w szczególności wówczas, gdy oddziały brytyjskie są odpowiedzialne za osoby zatrzymane i aresztowane ${ }^{20}$.

Omawiana doktryna brytyjska sporo uwagi poświęca przyjętemu w MPH rozróżnieniu na konflikty międzynarodowe i wewnętrzne, zakresowi zasad i norm MPH stosowanych w każdym z tych konfliktów, a także kwestii użycia siły i zgodności jej użycia z prawem konfliktów zbrojnych. W doktrynie zaakceptowano tradycyjny w prawie humanitarnym, dychotomiczny podział na dwa rodzaje konfliktów zbrojnych: wewnętrzne (niemiędzynarodowe) oraz międzynarodowe, wyjaśniając, iż wewnętrzny konflikt zbrojny toczy się między siłami zbrojnymi państwa i jedną lub więcej niż jedną frakcją zbrojną w tym państwie lub między takimi frakcjami na terenie jednego państwa. Jeśli oddziały zbrojne zaangażowane są w kampanię przeciwpowstańcza, która stanowi, bądź obejmuje, konflikt między dwoma lub więcej państwami, wówczas będzie ona międzynarodowym konfliktem zbrojnym. Warto podkreślić, iż decyzja w kwestii uznania, czy powstanie osiągnęło pułap konfliktu zbrojnego, a jeśli tak, czy jest to konflikt wewnętrzny czy międzynarodowy, należy do brytyjskiego rządu ${ }^{21}$.

W odniesieniu do zasad i norm prawa konfliktów zbrojnych znajdujących zastosowanie podczas operacji typu COIN, omawiany podręcznik z 2009 r. pokrótce charakteryzuje cztery podstawowe zasady tego prawa - konieczności wojskowej, humanitaryzmu, rozróżniania i proporcjonalności - zasadniczo nie odbiegając od powszechnie przyjętych $\mathrm{w}$ prawie traktatowym i zwyczajowym definicji. Wyjaśniono więc, że konieczność wojskowa zezwala państwu zaangażowanemu w konflikt zbrojny na użycie tylko takiego stopnia i rodzaju siły, w granicach wyznaczonych przez

${ }^{19}$ Zob. art. 2 wspólny dla konwencji genewskich o ochronie ofiar wojny: I - o polepszeniu losu rannych i chorych w armiach czynnych [dalej: KG I]; II - o polepszeniu losu rannych, chorych i rozbitków sił zbrojnych na morzu [dalej: KG II]; III - o traktowaniu jeńców wojennych [dalej: KG III]; IV - o ochronie osób cywilnych podczas wojny [dalej: KG IV], Genewa, 12 sierpnia 1949 r., Dz. U. z 1956 r. Nr 38, poz. 171, załącznik; a także art. 1 ust. 3 Protokołu Dodatkowego I do konwencji genewskich z 12 sierpnia 1949 r., dotyczącego ochrony ofiar międzynarodowych konfliktów zbrojnych [dalej: PD I] oraz art. 1 Protokołu Dodatkowego II do konwencji genewskich z 12 sierpnia 1949 r., dotyczącego ochrony ofiar niemiędzynarodowych konfliktów zbrojnych [dalej: PD II], Genewa, 8 czerwca 1977 r., Dz. U. z 1992 r. Nr 41, poz. 175, załącznik.

${ }^{20}$ AFM Countering Insurgency, p. 12-5.

${ }^{21}$ Tamże, p. 12-10. 
MPH, które jest wymagane, by osiagnnąć dozwolony cel konfliktu, jakim jest całkowita lub częściowa kapitulacja powstańców, przy jak najmniejszym nakładzie czasu oraz zasobów ludzkich i materialnych ${ }^{22}$. Zasada humanitaryzmu w brytyjskiej doktrynie przyjęła właściwie formę zakazu powodowania nadmiernego cierpienia, ponieważ zdefiniowano ją jako zasadę zabraniającą zadawania cierpień bądź ran, albo powodowania zniszczeń, które nie są rzeczywiście konieczne do osiągnięcia dozwolonych celów wojskowych ${ }^{23}$. Biorąc pod uwagę, że operacje militarne w ramach zwalczania powstania skierowane są przeciw siłom zbrojnym powstańców oraz celom wojskowym, zasada rozróżniania wymaga wprowadzenia wyraźnej różnicy między traktowaniem kombatantów i nie-kombatantów oraz między obiektami, które mogą być zgodnie z prawem celem ataku i tymi, które są przed atakiem chronione ${ }^{24}$. Ponadto zakazane są ataki bez rozróżnienia (indiscriminate attacks) ${ }^{25}$. Wreszcie, zasada proporcjonalności - w rozumieniu MPH - wymaga, by niedające się uniknąć straty (takie jak przypadkowe ofiary wśród osób cywilnych i niezamierzone szkody w mieniu ludności cywilnej) będące rezultatem dozwolonej akcji zbrojnej, nie były nadmierne w stosunku do bezpośredniej i konkretnej korzyści wojskowej oczekiwanej po ataku ocenianym - co istotne - całościowo, nie zaś tylko traktowanym $\mathrm{w}$ odizolowaniu lub w odniesieniu do jego poszczególnych części ${ }^{26}$. Tym samym, ocena proporcjonalności przy każdej

${ }^{22}$ Tamże, p. 12-17. Zob. wyrok Amerykańskiego Trybunału Wojskowego w sprawie Wilhelma Lista - Wilhelm List et al. (Hostages Trial), Case No. 47, U.S. Military Tribunal, Nuremberg, 8 July 1947-19 February 1948, [w:] Law Reports of Trials of War Criminals, vol. VIII, London 1949, s. 66. Zob. też Y. Sandoz, Ch. Swinarski, B. Zimmermann (red.), Commentary on the Additional Protocols of 8 June 1977 to the Geneva Conventions of 12 August 1949, Geneva 1987 (art. 35), par. 1397.

${ }^{23}$ Zob. art. 35 PD I. Zob. też zasada 70, [w:] J.-M. Henckaerts, Studium poświęcone zwyczajowemu międzynarodowemu prawu humanitarnemu: wkład w zrozumienie i poszanowanie zasad prawa dotyczacych konfliktu zbrojnego, tłum. M. Sajkowski, Warszawa 2006, s. 37.

${ }^{24}$ AFM Countering Insurgency, p. 12-17. Zob. art. 48 PD I. Zob. też zasada 1, [w:] J.-M. Henckaerts, Studium, s. 30.

${ }^{25}$ Zob. art. 51 ust. 4 PD I. Zob. też zasady 11-13, [w:] J.-M. Henckaerts, Studium, s. 31.

${ }^{26}$ AFM Countering Insurgency, p. 12-17. Odmiennie uważają autorzy komentarza do Protokołu Dodatkowego I, według których korzyść wojskowa powinna być mierzona w oparciu o konkretny cel taktyczny danej akcji, bowiem korzyść wojskowa w ujęciu kumulatywnym jest, przynajmniej w większości przypadków, „ledwo zauważalna” $\mathrm{i}$ „osiągalna jedynie w dłuższej perspektywie” (Y. Sandoz, Ch. Swinarski, B. Zimmermann (red.), Commentary, s. 684, par. 2209). Jak jednak zaznacza N. Neuman, praktyka państw wskazuje na szerszą akceptację poglądu, w świetle którego osiągniętą korzyść wojskową należy oceniać jako efekt całej operacji, a nie pojedynczej akcji zbrojnej (N. Neuman, Applying the Rule of Proportionality: Force Protection and Cumulative Assessment in International Law 
akcji zbrojnej powinna uwzględniać priorytetowy cel operacji przeciwpowstańczych, jakim jest zdobywanie poparcia ludności.

Twórcy doktryny zaznaczyli oczywiście, że prawo konfliktów zbrojnych to nie tylko podstawowe zasady, lecz wiele bardziej szczegółowych norm, z których część stosuje się tylko do jednego rodzaju konfliktów (np. tylko do międzynarodowych), a część znajduje zastosowanie w obu rodzajach. Podkreślono przy tym, że prawo regulujące konflikty wewnętrzne ma bardziej ograniczony zakres - prawo to obejmuje głównie art. 3 wspólny dla czterech konwencji genewskich z 1949 r. (obowiązujący wszystkie państwa) oraz Protokół Dodatkowy II z 1977 r. Zważywszy, że operacje przeciwpowstańcze toczą się przede wszystkim w warunkach konfliktu wewnętrznego, w doktrynie wymieniono, jakie obowiązki nakłada na państwa art. 3 wspólny ${ }^{27}$. Jeśli zaś chodzi o Protokół Dodatkowy II, wskazano tylko, że znajduje on zastosowanie jedynie w przypadku konfliktu zbrojnego państwa-strony PD II, na jego terytorium, z rozłamowymi siłami zbrojnymi, wystarczająco zorganizowanymi, by pozostawać pod odpowiedzialnym dowództwem i sprawować taką kontrolę nad częścią terytorium tego państwa, że mogą one przeprowadzać ciągłe i spójne operacje wojskowe ${ }^{28}$.

W odniesieniu do kwestii użycia siły przez oddziały brytyjskie, tzw. ofensywne jej użycie (tzn. wykraczające poza to, co jest dozwolone w ramach samoobrony) może nastąpić jedynie wówczas, gdy jest ono zgodne

and Morality, „Yearbook of International Humanitarian Law” 2004, vol. 7, s. 99-100). Zob. International Criminal Tribunal for the Former Yugoslavia, Final Report to the Prosecutor by the Committee Established to Review the NATO Bombing Campaign Against the Federal Republic of Yugoslavia, http://www.icty.org/x/file/Press/nato061300.pdf, par. 52 [dostęp: 14.10.2015 r.]. W odniesieniu do korzyści wojskowej, "podejście kumulatywne” prezentuje również Rzymski Statut Międzynarodowego Trybunału Karnego, Dz. U. z 2003 r. Nr 78, poz. 708 - w świetle art. 8 lit. b) pkt iv, zabroniony jest atak, który powoduje „przypadkową utratę życia lub zranienie osób cywilnych lub szkodę w obiektach cywilnych (...), które byłyby wyraźnie nadmierne w stosunku do konkretnej, bezpośredniej i całkowitej spodziewanej korzyści wojskowej" (podkr. aut.).

${ }_{27}$ Zob. AFM Countering Insurgency, p. 12-12.

${ }^{28}$ Tamże, p. 12-11. Zob. art. 1 ust. 1 PD II. Znamienne, że w doktrynie nie wspomniano ani o „innych zorganizowanych uzbrojonych grupach”, ani o stosowaniu PD II przez aktorów niepaństwowych (art. 1 ust. 2 in fine). Wydaje się jednak, że nie jest to błąd lub niedopatrzenie, ponieważ w punkcie 12-11 omawianej doktryny znajduje się wyraźne odesłanie do rozdziału 15 podręcznika brytyjskiej armii dotyczącego prawa konfliktów zbrojnych (JSP 383 - The Joint Service Manual of the Law of Armed Conflict, Joint Service Publication 2004), w którym określono szczegółowo zakres prawa stosowanego w wewnętrznych konfliktach zbrojnych. 
z prawem konfliktów zbrojnych i w takim zakresie, w jakim użycie siły prawo to wyznacza ${ }^{29}$. Jeśli poziom przemocy w danym państwie nie przekracza granic sytuacji, którą można scharakteryzować jako wewnętrzne zamieszki i niepokoje (takie jak rozruchy oraz odosobnione i sporadyczne akty przemocy), wówczas prawo konfliktów zbrojnych nie znajduje zastosowania, a siły brytyjskie nie będą uprawnione do ofensywnego użycia siły $^{30}$. Dziedziną prawa międzynarodowego odpowiednią w takich sytuacjach jest międzynarodowe prawo praw człowieka (obejmujące prawo do życia). Jeśli zaś powstanie $\mathrm{w}$ danym państwie osiagnie poziom przemocy, który odpowiada warunkom zaistnienia konfliktu zbrojnego, wówczas siły brytyjskie mogą zostać upoważnione do ofensywnego użycia siły zgodnie z prawem konfliktów zbrojnych ${ }^{31}$.

W omawianej doktrynie podkreślono również konieczność odpowiedniego postępowania z osobami zatrzymanymi, którymi mogą być przestępcy lub internowani z powodów bezpieczeństwa. Bez względu jednak na ich status, od chwili ich zatrzymania do chwili uwolnienia należy traktować ich w sposób humanitarny ${ }^{32}$. Jeśli zasady użycia siły upoważniają oddziały brytyjskie do przetrzymywania lub internowania osób przez dłuższy okres czasu, osoby takie należy umieścić w odpowiednio przygotowanych i wyposażonych obiektach (miejscach odosobnienia), zgodnie z właściwym prawem (prawem konfliktów zbrojnych i/lub standardami w zakresie praw człowieka) $)^{33}$. Personel wojskowy pracujący w tych obiektach powinien być odpowiednio wyszkolony, zorganizowany i wyposażony. Ponadto wojskowy doradca prawny (LEGAD) powinien uczestniczyć $\mathrm{w}$ planowaniu i prowadzeniu wszelkich operacji związanych z zatrzymywaniem osób, by zapewnić, że zgromadzone informacje i dowody są wystarczające w celu uzasadnienia konieczności uwięzienia/internowania oraz że warunki tych operacji spełniają międzynarodowe standardy. Postępowanie ze schwytanym personelem (niezależnie od tego, czy będą to jeńcy, zatrzymani czy internowani) wymaga odpowiedniej koordynacji w celu utrzymania właściwych standardów w miejscach odosobnienia

\footnotetext{
29 AFM Countering Insurgency, p. 12-13.

${ }^{30}$ Zob. art. 1 ust. 2 PD II.

31 AFM Countering Insurgency, p. 12-15.

${ }^{32}$ Zob. art. 3 wspólny dla KG (p. 1); art. 75 PD I; art. 5 PD II.

${ }^{33}$ Zob. dział II rozdział II KG III; dział IV rozdział II KG IV; art. 5 ust. 2 lit. c) PD II.
} 
oraz zagwarantowania regularnych, okresowych rewizji powodów, dla których osoby uwięzione/internowane zostały pozbawione wolności ${ }^{34}$.

\section{Doktryna amerykańska z 2014 r.}

Z historycznego punktu widzenia, pierwsze amerykańskie doświadczenia dotyczące walki powstańczej wiążą się z wojną o niepodległość i wojną secesyjną. W roli państwa zwalczającego powstanie Stany Zjednoczone wystąpiły natomiast w 1899 r. na Filipinach, walcząc przeciw oddziałom powstańczym, którym przewodził Emilio Aguinaldo. W okresie „zimnej wojny" USA zaangażowały się m.in. w wojnę domową w Grecji (od 1947 r.), wspierając stronę rządowa, w walkę z komunistyczną rebelią Hukbalahap na Filipinach (w latach pięćdziesiątych) oraz - co jest najbardziej znanym przykładem - w konflikt zbrojny w Wietnamie. Amerykańska koncepcja walki z Wietkongiem zdominowana jednak została przez doświadczenia wyniesione z II wojny światowej: próbowano osiągnąć sukces militarny wykorzystując zmasowaną siłę ognia i znaczącą przewagę technologiczną. Tak od strony strategicznej, jak i psychologicznej, podejście to było nie tylko niedopasowane do sytuacji panującej w Wietnamie, lecz także całkowicie odmienne od rozsądnej doktryny przeciwpowstańczej $^{35}$. W podobny, konwencjonalny sposób - wykorzystując zdecydowaną przewagę technologiczna, operacyjną i taktyczną - Amerykanie (i ich sojusznicy) postanowili potraktować XXI-wieczne konflikty w Iraku i Afganistanie $^{36}$. Okazało się jednak, że „rozproszeni, źle uzbrojeni i wyszkoleni $\mathrm{w}$ partyzanckich warunkach bojownicy, po początkowym rozbiciu, rosną w siłę i są w stanie zadawać Zachodowi dotkliwe ciosy, m.in. dzięki popar-

${ }^{34}$ AFM Countering Insurgency, p. 12-22. Zob. art. 78 KG IV; art. 75 ust. 3 PD I.

35 A.J. Joes, Guerrilla, s. 186-187. Zdaniem T. Mockaitisa, działania amerykańskie w Wietnamie nigdy nie były klasyczną kampanią przeciwpowstańczą (T.R. Mockaitis, The Phoenix, s. 14). Krytycznie (aczkolwiek nie bezstronnie) na temat militarnego zaangażowania Stanów Zjednoczonych w konflikt wietnamski - zob. M. Wolin, Agresja amerykańska w Wietnamie. Problemy wojskowe i polityczne, Warszawa 1967 (w szczególności rozdział IV, dotyczący m.in. rodzajów i sposobów prowadzenia operacji przeciwpartyzanckich).

${ }_{36}$ Wojna w Zatoce Perskiej w 1991 r. niejako utwierdziła Stany Zjednoczone w przekonaniu, że do konfliktów zbrojnych należy mieć podejście „czysto kinetyczne” (T.R. Mockaitis, The Phoenix, s. 10). 
ciu ludności lokalnej"37. Dopiero w latach 2004-2005 amerykańskie agencje wojskowe dokonały krytycznej oceny amerykańskich działań w Iraku, co zaowocowało publikacją w 2006 r. kompleksowego podręcznika dotyczącego zwalczania powstania - Counterinsurgency Field Manual (FM 3-24) ${ }^{38}$. Podręcznik ten wypełnił istotną lukę w amerykańskiej myśli wojskowej, przyjmując populacjocentryczne podejście w odniesieniu do strategii przeciwpowstańczej ${ }^{39}$ i w sposób kompleksowy formułując wytyczne dla oddziałów walczących lub szkolonych do udziału w operacjach typu COIN.

Przyjęty w 2014 r. podręcznik w pewnym zakresie nawiązuje do swojego poprzednika z 2006 r., różni się jednak od niego od strony technicznej, choć również tworzy ramy dla szerokiego spektrum działań wojsk lądowych, mających na celu przeciwdziałanie powstaniom lub ich zwalczanie. Nowy tytuł - Powstania i sposoby ich zwalczania (Insurgencies and Countering Insurgencies) sugeruje nacisk położony na zrozumienie sposobu myślenia i postępowania organizacji powstańczych, by móc z nimi skutecznie walczyć i odnieść ostateczny sukces. Ogólnie rzecz ujmując, podręcznik dzieli się na trzy części: część 1 omawia kontekst strategiczny i operacyjny, w części 2 uwagę poświęcono zrozumieniu powstania, a część 3 opisuje doktrynę jego zwalczania. Innymi słowy, podręcznik omawia kontekst problemu, sam problem oraz potencjalne rozwiązania ${ }^{40}$.

Zagadnienia dotyczące MPH stanowią znaczącą część rozdziału 13 omawianego podręcznika ${ }^{41}$. Już na wstępie rozważań na temat "prawa wojennego" ${ }^{\prime 2}$ wyjaśniono, iż operacje COIN mogą mieć miejsce zarówno $\mathrm{w}$ trakcie międzynarodowego konfliktu zbrojnego (państwo przeciwko

${ }^{37}$ H. Schreiber, Świadomość międzykulturowa. Od militaryzacji antropologii do antropologizacji wojska, Warszawa 2013, s. 13.

${ }^{38}$ Counterinsurgency Field Manual (FM) 3-24/Marine Corps Warfighting Publication (MCWP) 3-33.5, Headquarters Department of the Army, December 2006. Zob. też H. Schreiber, Świadomość, s. 257.

${ }^{39} \mathrm{~W}$ amerykańskim podręczniku z 2014 r. „zwalczanie powstania” to „kompleksowe działania o charakterze cywilnym i wojskowym nakierowane na jednoczesne pokonanie i wygaszenie powstania oraz zmierzenie się z jego źródłami" (FM 3-24/MCWP 3-33.5, Glossary (section II - Terms), s. 2).

${ }^{40}$ FM 3-24/MCWP 3-33.5 - Introduction, s. vii.

${ }^{41}$ Zob. FM 3-24/MCWP 3-33.5 - Chapter 13 (Legal Considerations), p. 13-10 - 13-36 oraz 13-42.

${ }^{42}$ W omawianym podręczniku posłużono się terminem law of war, wyjaśniono jednak, że jest to dziedzina prawa międzynarodowego regulująca prowadzenie konfliktów zbrojnych i dotycząca praw i relacji między uczestnikami i ofiarami tych konfliktów, często określana mianem „prawa konfliktów zbrojnych” (law of armed conflict) lub „międzynarodowego prawa humanitarnego" (international humanitarian law) - tamże, p. 13-11. 
państwu), jak i w przypadku niemiędzynarodowego konfliktu zbrojnego (państwo przeciwko niepaństwowej grupie zbrojnej). Konflikt zbrojny istnieje zawsze, gdy dochodzi do użycia siły pomiędzy państwami (w przypadku międzynarodowego konfliktu zbrojnego) lub przedłużającej się przemocy zbrojnej pomiędzy organami rządowymi, a zorganizowanymi grupami zbrojnymi bądź pomiędzy takimi grupami na obszarze danego państwa (w przypadku niemiędzynarodowego konfliktu zbrojnego). Niezależnie jednak od kontekstu, wojska amerykańskie przestrzegają prawa wojennego, zawartego w przyjętych przez Stany Zjednoczone traktatach dotyczących tego prawa oraz $\mathrm{w}$ obowiązujących normach zwyczajowego prawa międzynarodowego ${ }^{43}$.

Zakres regulacji prawa wojennego określono jasno i zwięźle - w sensie ogólnym, prawo to reguluje użycie siły w stopniu koniecznym do osiągnięcia celu konfliktu zbrojnego oraz chroni tych, którzy nie uczestniczą lub przestali bezpośrednio uczestniczyć w działaniach zbrojnych ${ }^{44}$. Zwrócono również uwagę, że przestrzeganie prawa wojennego pozwala osiągnąć amerykańskim siłom zbrojnym istotne cele, takie jak: utrzymanie dyscypliny, prowadzenie walki w zgodzie z amerykańskimi wartościami, zapewnienie wsparcia międzynarodowego, krajowego i lokalnego, ochrona kombatantów, niekombatanów i osób cywilnych przed niepotrzebnym cierpieniem, zapewnienie ochrony osobom, które znalazły się w rękach nieprzyjaciela oraz umożliwienie przywrócenia pokoju ${ }^{45}$. Jeśli chodzi o źródła prawa wojennego, wymieniono zwyczajowe MPH i podano przykłady międzynarodowych konwencji dotyczących tego prawa, w tym oba Protokoły Dodatkowe do konwencji genewskich, zastrzegając, że Stany Zjednoczone nie są ich strona, ale uważają że wiele postanowień PD I i PD II jest zgodnych z przyjętą przez USA praktyką ${ }^{46}$.

W omawianej doktrynie wiele miejsca poświęcono podstawowym zasadom prawa wojennego, podkreślając ich znaczenie dla prowadzenia działań zbrojnych przeciw powstańcom ${ }^{47}$. Do zasad tych zaliczono:

${ }^{43}$ Tamże, p. 13-10. Przyjęto też ogólną regułę, zgodnie z którą członkowie sił zbrojnych Stanów Zjednoczonych przestrzegają prawa wojennego podczas każdego konfliktu zbrojnego, bez względu na jego charakter (międzynarodowy lub niemiędzynarodowy) oraz w przypadku każdej innej operacji wojskowej (tamże, p. 13-30).

${ }_{44}$ Tamże, p. 13-11.

${ }_{45}$ Tamże.

46 Tamże, p. 13-12.

${ }^{47} \mathrm{~W}$ istocie, podstawowe zasady MPH są brane pod uwagę przy interpretacji wszystkich innych norm tego prawa i często bywają jedynym kryterium pozwalającym na ocenę 
1) konieczność wojskowa, zgodnie z którą strona walcząca może stosować takie środki, niezabronione w prawie międzynarodowym, które są niezbędne do całkowitego pokonania przeciwnika w możliwie najkrótszym czasie;

2) zasadę humanitaryzmu, która zabrania siłom zbrojnym stosowania wobec przeciwnika niepotrzebnej i nieuzasadnionej przemocy;

3) zasadę rozróżniania (określoną w podręczniku jako discrimination), która wymaga, by ataki zbrojne skierowane były przeciw kombatantom i innym celom wojskowym, a nie przeciw osobom cywilnym i ich mieniu;

4) zasadę proporcjonalności, w świetle której zakładane przypadkowe straty w życiu ludzkim, ranienia osób cywilnych oraz szkody $\mathrm{w}$ dobrach o charakterze cywilnym nie mogą być nadmierne w stosunku do oczekiwanej konkretnej i bezpośredniej korzyści wojskowej ${ }^{48}$.

Kolejne postanowienia omawianego podręcznika (punkty od 13-14 do 13-28) stanowią uszczegółowienie wymienionych wyżej podstawowych zasad prawa wojennego. Ich treść zasadniczo nie różni się od treści analogicznych postanowień traktatowych, ich dokładne przytaczanie nie wydaje się więc ani konieczne, ani celowe, warto jednak zwrócić uwagę na te postanowienia, które zawierają swoistą interpretację tych zasad, zwłaszcza w kontekście specyfiki operacji przeciwpowstańczych.

W odniesieniu do konieczności wojskowej, amerykańska doktryna przeciwpowstańcza właściwie nie odbiega od ogólnie przyjętego rozumienia tej zasady, podkreślono jednak, iż żadna z konwencji dotyczących prawa wojennego nie zawiera definicji konieczności wojskowej, choć nawiązano do niej w art. 23 lit. g Regulaminu haskiego załączonego do IV Konwencji haskiej dotyczącej praw i zwyczajów wojny lądowej z 1907 r. ${ }^{49}$, jej rola została też uwzględniona w wielu konwencjach, których Stany Zjednoczone są stroną ${ }^{50}$. W doktrynie zaznaczono wyraźnie, że koniecz-

legalności stosowanych przez strony walczące metod i środków prowadzenia działań zbrojnych (zob. E. Mikos-Skuza, Wprowadzenie do międzynarodowego prawa humanitarnego konfliktów zbrojnych, [w:] K. Lankosz (red.), Międzynarodowe prawo humanitarne konfliktów zbrojnych, Dęblin 2006, s. 37; M. Marcinko, Podstawowe zasady międzynarodowego prawa humanitarnego konfliktów zbrojnych, [w:] Z. Falkowski, M. Marcinko (red.), Międzynarodowe prawo humanitarne konfliktów zbrojnych, Warszawa 2014, s. 60).

${ }^{48}$ FM 3-24/MCWP 3-33.5, p. 13-13.

49 Dz. U. z 1927 r. Nr 21, poz. 161.

${ }^{50}$ FM 3-24/MCWP 3-33.5, p. 13-14. 
nością wojskową nie można uzasadniać wszelkich działań zbrojnych i podano przykłady działań (określonych w traktatach międzynarodowych), które są bezwzględnie zakazane w prawie wojennym i których nie da się niczym usprawiedliwić. Zasada konieczności wojskowej zezwala więc na użycie siły wymaganej, by osiągnąć cele misji, zabrania jednak działań niezgodnych z prawem wojennym. Zasada ta powinna być stosowana $\mathrm{w}$ połączeniu z pozostałymi zasadami prawa wojennego, jak również z innymi, bardziej szczegółowymi ograniczeniami prawnymi określonymi w stosownych umowach międzynarodowych ${ }^{51}$.

Zasadę humanitaryzmu (wyrażoną w art. 22 i 23 lit. e Regulaminu haskiego z 1907 r.) uznano za równoznaczną z zakazem powodowania zbędnych cierpień lub nadmiernych obrażeń ${ }^{52}$, a oba zawarte w tym zakazie zwroty potraktowano jako synonimy, zaznaczając przy tym, że żaden $\mathrm{z}$ nich nie został zdefiniowany $\mathrm{w}$ prawie ${ }^{53}$, choć należy je rozumieć jako odnoszące się do ran zadanych osobom, nie zaś do szkód wyrządzonych obiektom. Według autorów doktryny, wspomniany zakaz zakłada, iż cierpienia kombatantów są czymś spodziewanym i zgodnym z prawem, nawet jeśli mogą prowadzić do ciężkich obrażeń lub utraty życia. W omawianej doktrynie przyjęto też, że cierpienia zadane bronią lub amunicją można uznać za zbędne tylko wówczas, jeśli:

1) ich wykorzystanie było obliczone na spowodowanie zbędnego cierpienia;

2) normalne użycie danej broni lub amunicji w sposób nieunikniony skutkuje powodowaniem obrażeń, których charakter jest uznawa-

51 Tamże, p. 13-15.

${ }^{52} \mathrm{~W}$ polskim tłumaczeniu art. 35 ust. 2 PD I użyto jedynie określenia „zbędne cierpienia”, podczas gdy w angielskiej wersji językowej przyjęto określenie „superfluous injury or unnecessary suffering".

${ }^{53}$ Próba zdefiniowania tych zwrotów została co prawda podjęta przez ekspertów z Międzynarodowego Komitetu Czerwonego Krzyża (w latach 1996-2001) w ramach projektu SIrUS (akronim angielskiego wyrażenia Superfluous Injury or Unnecessary Suffering), jednak silna krytyka projektu nie tylko ze strony środowisk wojskowych i przedstawicieli państw, lecz także specjalistów z zakresu nauk medycznych, doprowadziła do wycofania się MKCK z dalszej realizacji projektu. Założenia i rezultaty projektu SIrUS - zob. R.M. Coupland (red.), The SIrUS Project: Towards a determination of which weapons cause "superfluous injury or unnecessary suffering" International Committee of the Red Cross, Geneva 1997. Na temat krytycznych opinii o projekcie zob. M. Marcinko, Projekt SIrUS i zakaz stosowania broni powodujacej nadmierne obrażenia i zbędne cierpienia, [w:] B. Janusz-Pawletta (red. nauk.), Prawne ograniczenia środków walki. Wybrane zagadnienia teorii i praktyki, „Zeszyt Problemowy Towarzystwa Wiedzy Obronnej" 2010, nr 3 (63), s. 94-98. 
ny przez państwa jako wyraźnie nieproporcjonalny do korzyści wojskowej oczekiwanej w związku z zastosowaniem tej broni lub amunicji ${ }^{54}$.

W podręczniku COIN podkreślono przy okazji, iż efekty broni lub amunicji należy oceniać $\mathrm{w}$ świetle porównywalnych i dozwolonych rodzajów broni i amunicji używanych na współczesnym polu walki. Broń nie może zatem zostać uznana za zakazaną tylko dlatego, że może powodować poważne cierpienie lub ciężkie rany. Właściwym determinantem oceny powinno być to, czy zastosowanie broni lub amunicji w sposób, w jaki została ona do tego przeznaczona, mogłoby zostać uznane za zakazane w pewnych lub w każdych okolicznościach. O zakazie można mówić wówczas, gdy zastosowanie danej broni lub amunicji zgodnie z jej przeznaczeniem nieuchronnie prowadzi do obrażeń lub cierpienia wyraźnie nieproporcjonalnego do jej skuteczności militarnej. Poza tym, państwo nie jest w stanie przewidzieć lub założyć wszelkich możliwych sposobów użycia broni lub amunicji, ponieważ niemal każdą broń lub amunicję można wykorzystać w sposób, który będzie zakazany ${ }^{55}$.

Przy okazji zasady humanitaryzmu zwrócono uwagę, że zgodnie z prawem wojennym kombatanci mogą zabijać lub ranić kombatantów przeciwnika albo osoby cywilne bezpośrednio uczestniczące $\mathrm{w}$ działaniach zbrojnych, o ile kombatanci stosują się do zakazów i ograniczeń dotyczących metod i środków walki. Zakaz powodowania zbędnych cierpień nie ogranicza jednak kombatantów, którzy wykorzystują miażdżącą przewagę w zakresie siły ognia, by zmusić oddziały wroga do poddania się lub by je pokonać. Prawo wojenne zabrania natomiast projektowania, modyfikacji bądź wykorzystania broni lub amunicji w celu zwiększania lub wywoływania cierpienia przekraczającego granice konieczności wojskowej56.

Zasada rozróżniania (principle of distinction) została w amerykańskim podręczniku COIN określona jako principle of discrimination, choć jego autorzy wyjaśniają że w sensie prawnym chodzi o tę samą zasadę. Sformułowano ją w sposób nieodbiegający od regulacji traktatowych i zwyczajowych $^{57}$, w odniesieniu do celów wojskowych podkreślono jednak, że taki cel nie ogranicza się tylko do baz wojskowych, sił zbrojnych czy wypo-

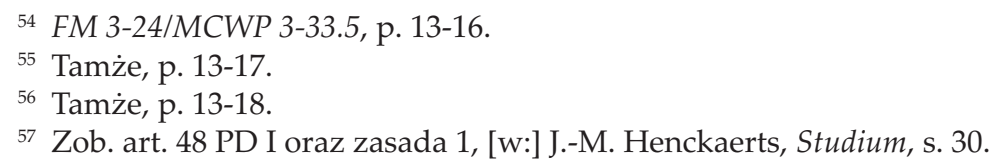


sażenia wojskowego, lecz obejmuje również inne obiekty, które wnoszą wkład w zdolności przeciwnika w zakresie prowadzenia działań zbrojnych - co stanowi zresztą potwierdzenie szerokiego rozumienia „wspierania wysiłku wojennego" przez armię Stanów Zjednoczonych ${ }^{58}$. Poza tym, obiekt cywilny jest chroniony przed bezpośrednim atakiem, chyba że przeciwnik pozbawi taki obiekt ochrony, wykorzystując go niezgodnie $\mathrm{z}$ jego charakterem. Przed bezpośrednim atakiem omawiana zasada chroni ponadto osoby cywilne, do czasu, aż osoby te wezmą udział we wrogich działaniach wobec sił zbrojnych ${ }^{59}$.

Zarówno rząd i jego siły zbrojne, jak i niepaństwowe zorganizowane grupy zbrojne, mają obowiązek oddzielić personel wojskowy lub inne formacje przeznaczone do walki oraz obiekty wojskowe od ludności cywilnej i dóbr o charakterze cywilnym. Powinny też podejmować środki w celu ochrony tej ludności lub osób cywilnych znajdujących się na terytorium pod ich kontrola, np. poprzez ewakuację z obszarów objętych operacjami wojskowymi lub ostrzeżenia przed planowanymi nalotami. Należy również ograniczać działania lub unikać działań, które mogłyby narazić ludność cywilną na niebezpieczeństwa w związku z dozwolonymi operacjami wojskowymi prowadzonymi przez przeciwnika. W amerykańskim podręczniku z 2014 r. zakazano też wyraźnie wykorzystywania ludzi w charakterze „,żywych tarcz” (tak za ich zgoda, jak i bez niej) w celu ochrony obiektów i jednostek wojskowych oraz personelu wojskowego, uznając takie działanie za naruszenie zasady rozróżniania ${ }^{60}$.

W omawianym podręczniku COIN znalazło się ponadto odniesienie do stosowanej przez armię Stanów Zjednoczonych praktyki dotyczącej niepaństwowych grup zbrojnych. Taka grupa może bowiem zostać uznana za wrogą (co oznacza, że można ją atakować w każdym czasie), a jej członkowie mogą zostać uznani za bezpośrednio uczestniczących w działaniach zbrojnych, lecz tylko przez upoważnionego do tego funkcjonariusza państwowego. Jeśli do takiego uznania nie doszło, decyzja, czy dana osoba cywilna może stać się celem ataku zależy od tego, czy osoba

${ }^{58}$ Zob. definicje celów wojskowych przyjęte w wybranych amerykańskich podręcznikach wojskowych na stronie internetowej MKCK poświęconej zwyczajowemu międzynarodowemu prawu humanitarnemu (Customary IHL) - Practice Relating to Rule 8. Definition of Military Objectives (Section A. General), https://www.icrc.org/customary-ihl/ eng/docs/v2_rul_rule8_sectiona [dostęp: 12.11.2015 r.].

${ }^{59}$ FM 3-24/MCWP 3-33.5, p. 13-19.

${ }^{60}$ Tamże, p. 13-20. 
ta dopuszcza się czynu spełniającego przesłanki wrogiego działania lub wrogiego zamiaru, zgodnie ze stałymi zasadami użycia siły (standing rules of engagement). Poza tym, w przypadku konkretnego konfliktu mogą obowiązywać szczególne zasady użycia siły, które będą zawierały analizę (np. w formie procedury) pozwalającą określić bezpośredni udział $\mathrm{w}$ działaniach zbrojnych ${ }^{61}$.

Zasada proporcjonalności wymaga, aby spodziewane straty wśród ludności i zniszczenia mienia towarzyszące atakom nie były nadmierne w stosunku do oczekiwanej konkretnej i bezpośredniej korzyści wojskowej. Według autorów omawianego podręcznika zasada ta jest raczej zorientowana na procedury niż wynik. Od decydentów oczekuje się podjęcia wszelkich możliwych środków ostrożności podczas planowania operacji wojskowych. Problem w tym, że oficerowie planujący operacje i rozważający ryzyko, jakie operacje te mogą nieść dla ludności cywilnej, polegają na (często niekompletnych i niedokładnych) informacjach dostępnych $\mathrm{w}$ danym momencie. $\mathrm{W}$ tym kontekście, zasada proporcjonalności może być postrzegana jako filar, na bazie którego dowódcy powinni rozważyć niszczące, lecz dozwolone prawnie, skutki ataku (zgodnie z zasadą konieczności wojskowej) względem niepożądanych skutków ubocznych, jakie atak niesie (takich jak ryzyko spowodowania śmierci lub obrażeń ciała ludności cywilnej niebiorącej bezpośredniego udziału w walkach). Co istotne, zasadę proporcjonalności można stosować na poziomie krajowym, strategicznym, operacyjnym lub taktycznym ${ }^{62}$.

Zasada proporcjonalności nie wyklucza zatem zniszczeń uzasadnionych koniecznością wojskową ani nie ogranicza stopnia użycia siły wobec przeciwnika w przypadku braku osób lub obiektów cywilnych. W szczególności, nie zabrania stosowania przytłaczającej siły ognia wobec oddziałów wroga w celu ich pokonania lub zniszczenia. Nie wyklucza również obrażeń wśród ludności cywilnej będących następstwem legalnych operacji militarnych. W tym kontekście, zasada proporcjonalności uznaje przykra, lecz zgodną z prawem nieuchronność przypadkowych obrażeń wśród osób cywilnych niebiorących bezpośredniego udziału w działaniach zbrojnych bądź przypadkowych zniszczeń obiektów cywilnych pomimo stosowanych środków ostrożności - w trakcie realizacji dozwo-

\footnotetext{
61 Tamże, p. 13-25.

62 Tamże, p. 13-26.
} 
lonych operacji wojskowych, szczególnie w sytuacji, gdy nie można było oddzielić tych osób lub obiektów od celów wojskowych ${ }^{63}$.

Zasadę proporcjonalności powinien rozważyć dowódca, podejmując decyzję, czy zaangażowanie w działania ofensywne lub defensywne, którymi dowodzi, mogą spowodować przypadkową utratę życia i obrażenia osób cywilnych, zniszczenia obiektów cywilnych bądź obydwie te rzeczy naraz, które byłyby niewspółmierne do konkretnej i bezpośredniej korzyści wojskowej spodziewanej jako rezultat takich działań. Podobnie jak w przypadku doktryny brytyjskiej, doktryna amerykańska zakłada, iż oczekiwana korzyść wojskowa w zasadzie odnosi się do wspomnianych działań traktowanych jako całość, nie zaś traktowanych w oderwaniu od siebie czy w odniesieniu do pewnych ich części. Ogólnie rzecz biorąc, korzyść wojskowa nie ogranicza się do zdobyczy taktycznych, lecz odnosi się do pełnego spektrum strategii wojennej ${ }^{64}$.

Omówione zasady oraz ich elementy uproszczono i zebrano $\mathrm{w}$ formie dziesięciu podstawowych reguł, skierowanych do żołnierzy i marines służących w amerykańskiej armii:

„1) Żołnierze i Marines walczą tylko z kombatantami wroga.

2) Żołnierze i Marines nie ranią wrogów, którzy się poddali. Rozbrajają ich i przekazują swoim zwierzchnikom.

3) Żołnierze i Marines nie zabijają ani nie torturują jeńców wroga lub więźniów.

4) Żołnierze i Marines zbierają i udzielają pomocy rannym, zarówno sojusznikom, jak i wrogom.

5) Żołnierze i Marines nie atakują personelu, obiektów lub wyposażenia medycznego.

6) Żołnierze i Marines nie niszczą niczego ponad to, czego wymaga misja.

7) Żołnierze i Marines traktują wszystkie osoby cywilne humanitarnie.

8) Żołnierze i Marines nie kradną. Szanują własność i mienie prywatne.

9) Żołnierze i Marines czynią wszystko, by zapobiec naruszeniom prawa wojennego.

\footnotetext{
${ }^{63}$ Tamże, p. 13-27.

64 Tamże, p. 13-28.
} 
10) Żołnierze i Marines informują swojego przełożonego o wszelkich naruszeniach prawa wojennego" ${ }^{\prime 65}$.

Pomimo faktu, że do powstań może dochodzić w realiach konfliktu międzynarodowego (w tym w trakcie okupacji), tradycyjnie jednak są one konfliktami między państwami a zbrojnymi aktorami niepaństwowymi, zatem są one uznawane za niemiędzynarodowe konflikty zbrojne. Traktatowych regulacji prawa wojennego dotyczących takich konfliktów jest znacznie mniej niż w przypadku konfliktów międzynarodowych, mimo to bez wątpienia obowiązują $\mathrm{w}$ ich trakcie podstawowe zasady prawa wojennego. Autorzy omawianej doktryny zauważaja iż operacje przeciwpowstańcze wykazują typowe cechy przypisywane konfliktom niemiędzynarodowym, najczęściej występującej obecnie formie konfliktu zbrojnego, zwracają także szczególną uwagę na znaczenie art. 3 wspólnego dla konwencji genewskich z 1949 r., przede wszystkim z powodu podstawowej ochrony, jakiej oddziały amerykańskie powinny udzielić powstańcom i innym osobom schwytanym, nie zapominając przy tym o statusie, jaki powstańcom nadaje prawo wewnętrzne państwa-gospodarza ${ }^{66}$. Bez względu jednak na status prawny osób schwytanych, aresztowanych lub w jakikolwiek inny sposób przetrzymywanych przez siły zbrojne Stanów Zjednoczonych, osoby te należy traktować w sposób humanitarny i zapewnić im minimalny zakres ochrony przewidziany w art. 3 wspólnym dla konwencji genewskich. W przypadku zaś przedłużającego się okresu zatrzymania, wspomniane osoby powinny zostać umieszczone $\mathrm{w}$ odpowiednio zaprojektowanych i wyposażonych miejscach odosobnienia, a zajmować się nimi powinny specjalnie wyszkolone, zorganizowane i wyposażone jednostki żandarmerii wojskowej ${ }^{67}$.

Autorzy omawianej doktryny podsumowuja, że prawo wojenne jest niezwykle istotnym elementem operacji przeciwpowstańczych, bezpośrednio wspierającym osiągnięcie strategicznych celów misji, jakimi są pokonanie powstańców i ustanowienie lokalnej władzy poprzez zdobycie zaufania miejscowej ludności cywilnej lub przynajmniej przekonanie tej ludności, by zaprzestała aktywnie wspierać powstanie. Natomiast naruszenia prawa wojennego mają bezpośredni i zdecydowanie negatywny

\footnotetext{
${ }^{65}$ Tamże, p. 13-30.

${ }_{66}$ Tamże, p. 13-33 - 13-34.

67 Tamże, p. 13-42.
} 
wpływ na możliwość przeprowadzenia zwycięskiej operacji przeciwpowstańczej ${ }^{68}$.

\section{Doktryna Sojuszu Północnoatlantyckiego z 2011 r.}

Doktryna przeciwpowstańcza NATO przyjęta w 2011 r. zawiera instrukcje dla dowódców i personelu formacji i jednostek operacyjnych państw członkowskich biorących udział w operacjach mających na celu stłumienie lub powstrzymanie działań powstańców ${ }^{69}$. Opracowano ją do użytku na poziomie operacyjnym i taktycznym. Dokument ten zawiera informacje na temat kompleksowego środowiska operacyjnego, jego aktorów, jak również wszystkich istotnych czynników mających wpływ na prowadzenie operacji przeciwpowstańczych ${ }^{70}$. Co istotne, dokument ten odnosi się wyłącznie do przypadków operacji przeciwpowstańczych prowadzonych poza obszarem traktatowym NATO. Jeśli do powstania doszłoby na terytorium jednego z państw członkowskich, zastosowanie znajdują regulacje krajowe państwa dotkniętego wybuchem powstania ${ }^{71}$.

Jako organizacja międzynarodowa, Sojusz Północnoatlantycki posiada już zresztą pewne doświadczenie w prowadzeniu operacji przeciwpowstańczych. Zakończona w 2014 r. operacja ISAF (International Security Assistance Force) w Afganistanie była bowiem „klasyczną operacją antypartyzancką o charakterze asymetrycznym"72, w której afgańskie siły rządowe wraz z wojskami koalicji skupionymi wokół NATO prowadziły walkę na wyczerpanie z mniej lub bardziej zorganizowanymi ugrupowaniami bojowników, a punktem ciężkości toczonych walk było zdobycie przychylności ludności cywilnej ${ }^{73}$.

68 Tamże, p. 13-31.

${ }^{69}$ AJP-3.4.4, p. 0001. W świetle analizowanej doktryny Sojuszu z 2011 r., „,zwalczanie powstania" to „zestaw działań o charakterze politycznym, ekonomicznym, społecznym, militarnym, cywilnym, psychologicznym i w zakresie ochrony porządku publicznego, mających na celu stłumienie powstania i rozwiązanie głównych problemów" (AJP-3.4.4, p. 0325).

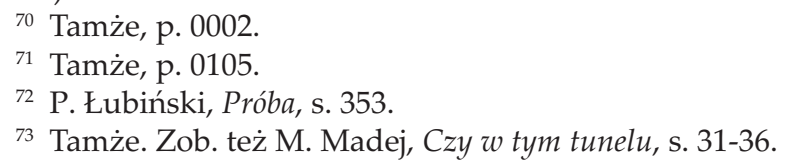


W przeciwieństwie jednak do dotychczas omawianych doktryn przeciwpowstańczych, doktryna NATO w swojej treści jedynie nawiązuje do obowiązku przestrzegania międzynarodowego prawa humanitarnego, nie formułując jednak właściwie żadnych konkretnych postanowień w tym zakresie. Brak też - wzorem doktryn brytyjskiej i amerykańskiej - odrębnego rozdziału poświęconego zagadnieniom prawnym. Autorzy doktryny Sojuszu wyszli bowiem z założenia, że prowadzenie operacji przeciwpowstańczych będzie zgodne $\mathrm{z}$ odpowiednimi normami prawa międzynarodowego, a ,jakiekolwiek postanowienia, definicje lub zobowiązania wynikające $\mathrm{z}$ omawianego dokumentu nie będą interpretowane bądź rozumiane jako praktyka państw czy zmiana obowiązujących umów dotyczących prawa konfliktów zbrojnych"74. Podkreślono również, że wszelkie sformułowania i terminologia związane ze zjawiskiem powstania oraz jego modelem organizacyjnym i operacyjnym nie mają na celu wprowadzania jakichkolwiek konotacji prawnych bądź określania statusu kombatanta, lecz mają pomóc dowódcom i personelowi NATO w zrozumieniu i opisaniu ich środowiska operacyjnego, a także w planowaniu i prowadzeniu operacji COIN 55 .

Takie ogólne, odsyłające do właściwych uregulowań międzynarodowych stanowisko wynikać może z faktu, że Sojusz Północnoatlantycki - wbrew obiegowej opinii - nie jest niezależnym podmiotem, funkcjonującym w oderwaniu od państw członkowskich. Sojusz postrzegać należy raczej jako mechanizm koordynujący działania grupy suwerennych państw, dysponujący środkami dostępnymi dla sojuszników w zależności od ich potrzeb ${ }^{76}$. Co więcej, działania podejmowane przez NATO w ramach prowadzenia operacji wojskowych realizują - z niewielkimi tylko wyjątkami - kontyngenty sił zbrojnych dostarczone i dowodzone przez uczestniczące w danej operacji państwa członkowskie (bądź przez partnerów Sojuszu), kontyngenty te podlegają też pełnej i zasadniczo stałej kontroli państw, z których pochodzą ${ }^{77}$.

74 AJP-3.4.4, p. 0103.

75 Tamże, p. 0104.

${ }^{76}$ Zob. P.M. Olson, A NATO perspective on applicability and application of IHL to multinational forces, „International Review of the Red Cross” 2013, vol. 95, No. 891/892, s. 654. Zob. L. Kjelgaard, The importance of the law in theatre, [w:] E. Greppi, G.L. Beruto (red.), Conduct of Hostilities: the Practice, the Law and the Future, 37 th Round Table on Current Issues of International Humanitarian Law (Sanremo, $4^{\text {th }}-6^{\text {th }}$ September 2014), International Institute of Humanitarian Law, Sanremo 2015, s. 35.

77 P.M. Olson, A NATO perspective, s. 654. 
Wszyscy członkowie NATO są stronami podstawowych traktatów w dziedzinie MPH - konwencji haskich z 1907 r. i konwencji genewskich z 1949 r. - są zatem zobowiązani do przestrzegania ich postanowień. Podzielają także wspólne stanowisko w kwestii zobowiązań wynikających dla państw ze zwyczajowego MPH. Co równie istotne, po niemal sześćdziesięciu latach kooperacji sojusznicy mają jednakowe wyobrażenie o tym, jak implementować zasady i normy prawa humanitarnego w trakcie operacji. Niemniej jednak, Sojusz tworzą państwa suwerenne, a zatem zarówno zakres ich międzynarodowoprawnych zobowiązań, jak i krajowe przepisy i procedury służące implementacji $\mathrm{MPH}$, znacząco się między sobą różnią. Tytułem przykładu, poszczególni członkowie NATO mają różny zakres zobowiązań dotyczących pewnych rodzajów broni, takich jak amunicja kasetowa czy miny przeciwpiechotne. Nawet, jeśli państwa członkowskie formalnie związane są tymi samymi zobowiązaniami międzynarodowymi, w praktyce mogą być one w pewnych sytuacjach różnie interpretowane, np. w przypadku określonych kategorii osób zatrzymanych i aresztowanych. Biorąc powyższe pod uwagę, trudno byłoby uzasadnić istnienie "doktryny NATO” w zakresie stosowania MPH $\mathrm{w}$ operacjach wojskowych Sojuszu ${ }^{78}$. Stosowanie prawa humanitarnego w operacjach NATO jest raczej odbiciem indywidualnych, wewnętrznych stanowisk prawnych dwudziestu ośmiu członków Sojuszu ${ }^{79}$.

Nie ulega jednak wątpliwości, że operacje NATO są planowane i prowadzone z pełnym poszanowaniem właściwych zasad i norm prawa międzynarodowego. W przypadku, gdy nie wszyscy sojusznicy są stronami tych samych konwencji międzynarodowych, np. Protokołu Dodatkowego I z 1977 r. lub Europejskiej Konwencji o ochronie praw człowieka i podstawowych wolności z 1950 r. ${ }^{80}$, Sojusz nie ustanawia wspólnego mianownika $\mathrm{w}$ zakresie stosowania MPH na najniższym poziomie, tylko przyjmuje podejście maksymalistyczne ${ }^{81}$. Wiąże się to ściśle z koniecznością wypracowania tzw. interoperacyjności prawnej (legal interoperability) - terminu, który można tłumaczyć jako dysponowanie wspólnym zbiorem reguł prawnych ${ }^{82}$. Koncepcja „interoperacyjności prawnej” wyniknę-

78 Tamże, s. 654-655.

${ }^{79}$ Zob. L. Kjelgaard, The importance, s. 35.

80 Dz. U. z 1993 r. Nr 61, poz. 284 z późn. zm.

${ }^{81}$ L. Kjelgaard, The importance, s. 36.

${ }^{82}$ Szerzej na ten temat zob. K. Abbott, A brief overview of legal interoperability challenges for NATO arising from the interrelationship between IHL and IHRL in light of the European Con- 
ła z potrzeby niwelowania różnic prawnych między członkami sił wielonarodowych, by móc jak najefektywniej prowadzić wspólne operacje, jednocześnie przestrzegając obowiązującego prawa. Zagwarantowanie, że $\mathrm{w}$ ramach prowadzonej operacji wielonarodowej uwzględniono różnice wynikające $\mathrm{z}$ ratyfikowania różnych konwencji międzynarodowych (które dodatkowo mogą być różnie interpretowane), stanowi dla państw uczestniczących $\mathrm{w}$ operacji nie lada wyzwanie ${ }^{83}$. W przypadku państw członkowskich NATO generalnie interoperacyjność prawna jest możliwa, ponieważ założenia doktrynalne i zasady użycia siły przyjmowane na potrzeby operacji prowadzonych w kontekście konfliktu zbrojnego są kształtowane przede wszystkim przez zasady i normy $\mathrm{MPH}^{84}$. Co więcej, jak pokazała operacja ISAF w Afganistanie, choć państwa członkowskie NATO mogły pozostać przy granicach dopuszczalności użycia siły zgodnych z prawem humanitarnym, były również w stanie - zważywszy na wymogi operacyjne i polityczne związane z zapewnieniem wsparcia miejscowej ludności - przyjąć bardziej restrykcyjne zasady regulujące użycie siły ${ }^{85}$.

Interoperacyjność w zakresie międzynarodowego prawa humanitarnego ułatwiają występujące $\mathrm{w}$ dokumentach NATO odniesienia do obowiązku przestrzegania tego prawa. Przykładowo, ogólne założenia dotyczące użycia siły przez wojska Sojuszu oraz ograniczenia związane z jej użyciem znaleźć można w doktrynie sojuszniczej z 2010 r., dotyczącej operacji reagowania kryzysowego spoza art. 5 Traktatu Waszyngtońskiego ${ }^{86}$, która ma charakter nadrzędny w stosunku do doktryny przeciwpowstańczej z 2011 r. Dowódcy NATO na każdym szczeblu dowodzenia powinni mieć świadomość znaczenia, jakie dla wiarygodności i legitymacji operacji ma właściwe użycie siły, którego ramy stanowią kompleksowe połączenie praw i obowiązków wynikających z mandatów międzynarodowych i kra-

vention on Human Rights, "International Review of the Red Cross" 2014, vol. 96, No. 893, s. 107-137. W Słowniku terminów i definicji NATO znaleźć można jedynie definicję interoperacyjności - jest to „zdolność do działania synergicznego podczas wspólnego wykonywania wyznaczonych zadań" (AAP-6 - Słownik terminów i definicji NATO, 2005).

${ }_{83}$ Zob. International humanitarian law and the challenges of contemporary armed conflicts, Report prepared by the International Committee of the Red Cross to the $31^{\text {st }}$ International Conference of the Red Cross and Red Crescent (31IC/11/5.1.2), Geneva, October 2011, s. 32-33.

${ }^{84}$ Zob. K. Abbott, A brief overview, s. 108.

85 Tamże, s. 136.

${ }^{86}$ AJP-3.4(A) - Allied Joint Doctrine for Non-Article 5 Crisis Response Operations, Ratification Draft 1, www.kam.lt/download/14142/ajp-3.4(a)\%20rd1.pdf [dostęp: 18.09.2015 r.]. 
jowych, Karty Narodów Zjednoczonych, odpowiednich zasad, regulacji i porozumień międzynarodowych, prawa konfliktów zbrojnych, prawa międzynarodowego oraz ustawodawstwa wewnętrznego. Dowódcy i ich podwładni powinni być zaznajomieni z jasno sformułowanymi regułami określającymi ich prawa i obowiązki w zakresie użycia siły militarnej, muszą też bezwzględnie stosować się do tych reguł ${ }^{87}$. Możliwość użycia siły wpływa bowiem na każdy aspekt misji, dlatego konieczna jest jej stała kontrola. Wszelkie przypadki użycia siły muszą być zgodne z postanowieniami prawa międzynarodowego oraz z rozwiniętymi w tym zakresie wytycznymi zawartymi w zasadach użycia siły (rules of engagement, ROE). W ramach realizacji misji, stopień użytej siły, intensywność jej użycia oraz czas trwania nie moga przekraczać poziomu niezbędnego do wykonywania zadań oraz osiągnięcia wyznaczonych celów misji ${ }^{88}$.

W omawianej doktrynie przeciwpowstańczej NATO wyraźnie podkreślono, że znaczenie działań i akcji planowanych i podejmowanych przeciwko powstańcom należy oceniać z punktu widzenia potencjalnych skutków, które mogą dotknąć ludność cywilną ${ }^{89}$. Przykładowo, ataki mające na celu zneutralizowanie grup powstańczych mogą mieć miejsce $\mathrm{w}$ obszarach zurbanizowanych, wśród lokalnej ludności, dlatego należy zachować szczególną ostrożność, by uniknąć niepotrzebnych strat i szkód, które z pewnością podważyłyby zasadność użycia siły ${ }^{90}$. Zauważalne jest więc wyraźnie populacjocentryczne podejście do realizacji operacji przeciwpowstańczych ${ }^{91}$. Neutralizacja powstańców stanowi istotny element operacji COIN, wymaga to jednak zastosowania odpowiednich sił, zdolnych do wykrycia, schwytania lub zwalczania powstańców, a także wprowadzania środków kontroli ludności. Nadmiernie restrykcyjne środki kontroli mogą jednak okazać się szkodliwe dla samych sił przeciwpowstańczych, podobnie jak fizyczna likwidacja rebeliantów może przynieść efekt przeciwny do zamierzonego, jeśli działanie to spowoduje nadmierne straty wśród ludności cywilnej i stanie się źródłem rozgoryczenia, przyczyniając

87 Tamże, p. 0210.

${ }_{88}$ Tamże, p. 0202.

89 AJP-3.4.4, p. 0341.

90 Tamże, p. 0567.

${ }^{91}$ Zob. M. Marszałek, Ogólne założenia reagowania kryzysowego Sojuszu Pótnocnoatlantyckiego poza obszarem traktatowym, [w:] M. Kun-Buczko, M. Przybysz (red.), Bezpieczeństwo w dobie globalizacji. Prawo i praktyka, Białystok 2011, s. 394. 
się do uznania ofiar za męczenników, rekrutacji nowych bojowników oraz chęci dokonania zemsty ${ }^{92}$.

Bardziej szczegółowo natomiast omawiana doktryna NATO odnosi się do kwestii poszanowania i przestrzegania zasad i norm prawa międzynarodowego (zatem nie tylko MPH) w przypadku osób schwytanych, zatrzymanych, aresztowanych lub internowanych. Podkreślono, że przestrzeganie wspomnianych zasad i norm może wymagać m.in. odpowiednio wyposażonych więzień i aresztów, specjalistycznego szkolenia personelu, rzetelnych okresowych inspekcji wszystkich ośrodków, w których przetrzymywane są osoby, a także niezależnej, zewnętrznej kontroli prowadzonej przez bezstronne organizacje, takie jak Międzynarodowy Komitet Czerwonego Krzyża. Cały personel sił sojuszniczych odpowiada też za działania zgodne z odpowiednimi wytycznymi dotyczącymi traktowania osób przebywających w miejscach odosobnienia. Personel musi być przez cały czas w pełni świadomy, że brak poszanowania lub złe traktowanie osób pozbawionych wolności stanowić będzie nie tylko naruszenie prawa, lecz także - z perspektywy celów operacji COIN - wpłynie negatywnie na wiarygodność sił przeciwpowstańczych oraz ich zdolność do wypełnienia misji $i^{93}$.

Jeśli to możliwe, osoby przetrzymywane w areszcie powinny być jak najszybciej postawione przed niezależnym i niezawisłym sądem, gwarantującym uczciwy proces. Co więcej, dowódcy wszystkich szczebli mają obowiązek dopilnować, by przekazanie danej osoby w ręce krajowego wymiaru sprawiedliwości nie naraziło tej osoby na niebezpieczeństwo tortur, nieludzkiego lub poniżającego traktowania czy karania. Przed przekazaniem należy więc przeanalizować wszelkie dostępne informacje co do skuteczności lokalnej policji, niezależności systemu sądowego oraz charakteru systemu penitencjarnego ${ }^{94}$.

\section{Zakończenie}

Doświadczenia wyniesione przez państwa zachodnie (przede wszystkim Francję, Wielką Brytanię i Stany Zjednoczone) z prowadzonych przez

\footnotetext{
92 AJP-3.4.4, p. 0353.

93 Tamże, p. 0450, lit. b.

94 Tamże, p. 0450, lit. d. Zob. art. 75 PD I.
} 
nie wojen kolonialnych i operacji militarnych przeciw reżimom komunistycznym w okresie "zimnej wojny” zaowocowały przekonaniem, że w zwalczaniu powstania bardziej efektywne są działania nakierowane na uzyskanie kontroli nad społeczeństwem i zapewnienie legitymacji społecznej władzom centralnym ${ }^{95}$. Sformułowane przez Brytyjczyków i zaakceptowane przez państwa NATO hasło „winning hearts and minds" wiąże się m.in. z budowaniem pozytywnego wizerunku sił przeciwpowstańczych i rządu, który nimi kieruje bądź który korzysta z pomocy zewnętrznej, udzielonej przez państwa trzecie lub organizację międzynarodowa $a^{96}$. Osiagnięcie tego celu wymaga prowadzenia operacji w ściśle wyznaczonych granicach prawa. Innymi słowy, jednym z kluczowych elementów skutecznej strategii przeciwpowstańczej jest zagwarantowanie, że wszelkie działania będą przebiegać z poszanowaniem prawa w szczególności zaś te działania, które wiążą się z użyciem siły ${ }^{97}$. Fizyczna walka z powstańcami (lub - używając terminu wojskowego - aktywność kinetyczna) nie może zatem być prowadzona z naruszeniem zasad i norm $\mathrm{MPH}$, dlatego w doktrynach przeciwpowstańczych powinny znaleźć się odpowiednie postanowienia, które wyraźnie podkreślają konieczność przestrzegania prawa humanitarnego.

Założenia populacjocentrycznego podejścia do operacji typu COIN, wraz ze szczególnym znaczeniem, jakie w realizacji celów tych operacji pełni MPH, niewątpliwie znalazły odzwierciedlenie w doktrynach przeciwpowstańczych przyjętych przez Wielką Brytanię, Stany Zjednoczone i Sojusz Północnoatlantycki. W każdej z tych doktryn kluczowe znaczenie przypisuje się planowaniu i prowadzeniu działań w taki sposób, by minimalizować straty wśród ludności cywilnej. Populacjocentryczny model operacji COIN ukierunkowany jest bowiem na ochronę lokalnej ludności i zdobywanie jej poparcia, w dalszej kolejności zaś na fizyczną eliminację powstańców ${ }^{98}$. W świetle omówionych doktryn, sukces operacji COIN może zostać osiągnięty wyłącznie dzięki odpowiedniemu stosowaniu zasady minimum siły, a z pewnością nie należy używać siły większej niż wymaga tego sytuacja.

${ }_{95}$ Zob. M. Madej, Czy w tym tunelu, s. 28.

${ }_{96}$ Zob. A. Alderson, O. Manea, Counterinsurgency as a Whole of Government Approach: Notes on the British Army Field Manual. An Interview with Colonel Alexander Alderson, "Small Wars Journal", 24 January 2011, http://smallwarsjournal.com/blog/journal/docs-temp/657manea.pdf [dostęp: 12.09.2015 r.].

97 Zob. M. Madej, Czy w tym tunelu, s. 30.

98 P. Łubiński, Próba, s. 354-355. 
Zamiast „chwytaći zabijać” powstańców, siły przeciwpowstańcze powinny skupić się przede wszystkim na „zdobywaniu serc i umysłów" miejscowej ludności. Takie podejście nakazuje podejmowanie szczególnych środków ostrożności w stosunku do tej ludności, może też prowadzić do przyjęcia zasad użycia siły, które będą bardziej restrykcyjne niż odpowiednie normy MPH zezwalające na te bądź inne działania zbrojne ${ }^{99}$.

Kompleksowe traktowanie działań zmierzających do stłumienia powstania, obejmujące zresztą nie tylko działania militarne (kinetyczne), lecz także szereg działań niemilitarnych (niekinetycznych) - politycznych, ekonomicznych, psychologicznych, porządkowych itd. - przy jednoczesnym zmaganiu się ze źródłami rebelii, stanowi cechę charakterystyczną omówionych doktryn. Jest to jedyna właściwa odpowiedź na złożoność problemu, jaki stanowią dzisiejsze powstania ${ }^{100}$. Wieloaspektowość zwalczania powstania w wydaniu współczesnym skłania zatem do sparafrazowania słynnego zdania sformułowanego przez sir Thomasa E. Lawrence’a: „Prowadzenie wojny przeciwko partyzantce jest kłopotliwe i długotrwałe tak, jak jedzenie zupy nożem” ${ }^{\prime 101}$. Dziś walka z „partyzantką" nadal jest trudna i skomplikowana, siły przeciwpowstańcze dysponują jednak o wiele szerszym arsenałem metod i środków (niekoniecznie w sensie militarnym), które pozwalają na bardziej skuteczne działania i mniej drastyczne rozwiązania. Prowadząc operację COIN, siły przeciwpowstańcze mogą więc - zamiast tradycyjnym „nożem” - posłużyć się bardziej uniwersalnym i zdecydowanie poręczniejszym „szwajcarskim nożem oficerskim” ${ }^{102}$, za który uznać można zarówno populacjocentryczne doktryny COIN, jak i przewidziane $\mathrm{w}$ nich środki. Bez względu jednak na przyjętą interpretację, istotny jest fakt, że jednym z kluczowych „ostrzy”, które służyć ma rozwiązaniu problemu powstania, jest obowiązek poszanowania i stosowania zasad i norm międzynarodowego prawa humanitarnego ${ }^{103}$.

${ }^{99}$ Ch. de Cock, Counter-Insurgency Operations in Afghanistan: What is the Applicable Law?, [w:] B. Janusz-Pawletta (red.), Konwencje Genewskie 60 lat później. Nowe wyzwania dla międzynarodowego prawa humanitarnego konfliktów zbrojnych, Warszawa 2010, s. 48.

100 Zob. A. Alderson, O. Manea, Counterinsurgency.

101 Cyt. za: H. Schreiber, Świadomość, s. 13.

102 Więcej na temat szwajcarskich noży oficerskich (popularnie zwanych szwajcarskimi scyzorykami) - zob. http://www.victorinox.com/pl/pl/Produkty/Szwajcarskie-no\%C5\%BCe-oficerskie/c/SAK [dostęp: 12.10 .2015 r.].

103 Zupełnym przypadkiem, wspomniany nóż oficerski wywodzi się z tego samego kraju, w którym powołano do życia MKCK i który może poszczycić się ogromnym wkładem w rozwój i upowszechnianie międzynarodowego prawa humanitarnego. 
Słowa kluczowe: międzynarodowe prawo humanitarne, prawo konfliktów zbrojnych, zwalczanie powstania, doktryny przeciwpowstańcze

\section{Bibliografia}

Abbott K., A brief overview of legal interoperability challenges for NATO arising from the interrelationship between IHL and IHRL in light of the European Convention on Human Rights, "International Review of the Red Cross” 2014, vol. 96, No. 893.

Alderson A., Manea O., Counterinsurgency as a Whole of Government Approach: Notes on the British Army Field Manual. An Interview with Colonel Alexander Alderson, „Small Wars Journal”, 24 January 2011, http://smallwarsjournal. com/blog/journal/docs-temp/657-manea.pdf

Banks W., Introduction - Shaping a Global Legal Framework for Counterinsurgency: Placing Postmodern War in Context, [w:] W. Banks (red.), Counterinsurgency Law: New Directions in Asymmetric Warfare, Oxford 2013.

Bulloch G., Case Study 1: The Development of Doctrine for Countering Insurgency. The British Experience, [w:] British Army Field Manual, Volume 1 Part 10 Countering Insurgency, Army Code 71876, October 2009.

Coupland R.M. (red.), The SIrUS Project: Towards a determination of which weapons cause "superfluous injury or unnecessary suffering" International Committee of the Red Cross, Geneva 1997.

Crawshaw M., The Evolution of British COIN, https://www.gov.uk/government/uploads/system/uploads/attachment_data/file/43334/jdp340theevolutionofbritishcoinbymichaelcrawshaw.pd $\bar{f}$

De Cock Ch., Counter-Insurgency Operations in Afghanistan: What is the Applicable Law?, [w:] B. Janusz-Pawletta (red.), Konwencje Genewskie 60 lat później. Nowe wyzwania dla międzynarodowego prawa humanitarnego konfliktów zbrojnych, Warszawa 2010.

Dixon P., "Hearts and Minds"? British Counter-Insurgency from Malaya to Iraq, "The Journal of Strategic Studies" 2009, vol. 32, No. 3.

Henckaerts J.-M., Studium poświęcone zwyczajowemu międzynarodowemu prawu humanitarnemu: wkład w zrozumienie i poszanowanie zasad prawa dotyczacych konfliktu zbrojnego, tłum. M. Sajkowski, Warszawa 2006.

Jackson A., British Counterinsurgency in History: A Useful Precedent?, „British Army Review" 2006, vol. 139.

Joes A.J., Guerrilla Warfare: A Historical, Biographical, and Bibliographical Sourcebook, Westport-London 1996.

Kjelgaard L., The importance of the law in theatre, [w:] E. Greppi, G.L. Beruto (red.), Conduct of Hostilities: the Practice, the Law and the Future, $37^{\text {th }}$ Round Table on Current Issues of International Humanitarian Law (Sanremo, $4^{\text {th }}-6^{\text {th }}$ September 2014), International Institute of Humanitarian Law, Sanremo 2015. 
Kruszyński B., Udział sił zbrojnych USA w konfliktach w Iraku i Afganistanie - największych wojnach przełomu XX/XXI wieku, Poznań 2011.

Łubiński P., Próba oceny wybranych aspektów polskiego zaangażowania w ramach misji ISAF w Afganistanie, [w:] M. Kun-Buczko, M. Przybysz (red.), Bezpieczeństwo w dobie globalizacji. Prawo i praktyka, Białystok 2011.

Madej M., Czy w tym tunelu jest światło? Operacja ISAF na tle klasycznych koncepcji zwalczania partyzantki, [w:] W. Sokała, B. Zapała (red.), Asymetria i hybrydowość - stare armie wobec nowych konfliktów, Warszawa 2011.

Marcinko M., Podstawowe zasady międzynarodowego prawa humanitarnego konfliktów zbrojnych, [w:] Z. Falkowski, M. Marcinko (red.), Międzynarodowe prawo humanitarne konfliktów zbrojnych, Warszawa 2014.

Marcinko M., Projekt SIrUS i zakaz stosowania broni powodujacej nadmierne obrażenia i zbędne cierpienia, [w:] B. Janusz-Pawletta B. (red. nauk.), Prawne ograniczenia środków walki. Wybrane zagadnienia teorii i praktyki, „Zeszyt Problemowy Towarzystwa Wiedzy Obronnej" 2010, nr 3 (63).

Marszałek M., Ogólne założenia reagowania kryzysowego Sojuszu Pótnocnoatlantyckiego poza obszarem traktatowym, [w:] M. Kun-Buczko, M. Przybysz (red.), Bezpieczeństwo w dobie globalizacji. Prawo i praktyka, Białystok 2011.

Marszałek M., Operacje reagowania kryzysowego NATO. Istota. Uwarunkowania. Planowanie, Warszawa 2013.

Mikos-Skuza E., Wprowadzenie do międzynarodowego prawa humanitarnego konfliktów zbrojnych, [w:] K. Lankosz (red.), Międzynarodowe prawo humanitarne konfliktów zbrojnych, Dęblin 2006.

Mockaitis T.R., The Phoenix of Counterinsurgency, „,The Journal of Conflict Studies" 2007, vol. 27, No. 1.

Neuman N., Applying the Rule of Proportionality: Force Protection and Cumulative Assessment in International Law and Morality, "Yearbook of International Humanitarian Law" 2004, vol. 7.

Olson P.M., A NATO perspective on applicability and application of IHL to multinational forces, „International Review of the Red Cross” 2013, vol. 95, No. $891 / 892$.

Sandoz Y., Swinarski Ch., Zimmermann B. (red.), Commentary on the Additional Protocols of 8 June 1977 to the Geneva Conventions of 12 August 1949, Geneva 1987.

Schreiber H., Świadomość międzykulturowa. Od militaryzacji antropologii do antropologizacji wojska, Warszawa 2013.

Sitaraman G., The Counterinsurgent's Constitution: Law in the Age of Small Wars, Oxford 2013.

Solarz J., Doktryny militarne XX wieku, Kraków 2009.

Strachan H., British Counterinsurgency from Malaya to Iraq, „Royal United Services Institute Journal" 2007, vol. 152, No. 6.

Więcek W. (red.), Działania przeciwrebelianckie w operacjach, Warszawa 2011.

Wolin M., Agresja amerykańska w Wietnamie. Problemy wojskowe i polityczne, Warszawa 1967. 


\section{THE IMPORTANCE \\ OF INTERNATIONAL HUMANITARIAN LAW IN COUNTERING INSURGENCY IN THE LIGHT OF SELECTED POPULATION-CENTRIC COUNTERINSURGENCY DOCTRINES}

\section{$S \mathbf{u m ~ m}$ a r y}

The accomplishment of so-called population-centric counterinsurgency (COIN) strategy, accepted by Western States, is significantly aided by International Humanitarian Law (IHL); one of the guarantees of successful population-centric COIN operations is respecting and applying IHL, in order to win the trust and support of the civilian population, which allows to alienate insurgents and deny them shelter and other forms of support offered by the local population and eventually to subdue and defeat the insurgency. Therefore, in counterinsurgency doctrines adopted by such countries as Great Britain and the United States, also in COIN doctrine adopted by NATO, the obligation to respect and obey the humanitarian law is perceived as a factor necessary in every action in which this law is to be applied (e.g. during combat missions against insurgents or in case of their capture). Each such doctrine contains provisions relating to IHL principles and norms although doctrines tend to differ when compared with one another in terms of the degree of detail in IHL references; furthermore, not all issues covered and regulated by the said law have been adequately addressed in their content.

Key words: international humanitarian law, law of armed conflict, counterinsurgency, counterinsurgency doctrines

\section{ЗНАЧЕНИЕ МЕЖДУНАРОДНОГО ГУМАНИТАРНОГО ПРАВА В БОРЬБЕ С ВОССТАНИЕМ В СВЕТЕ ИЗБРАННЫХ НАРОДОНАСЕ ЛЕНИХ ПРОТИВОПОВСТАНЧЕСКИХ ДОКТРИН}

\section{P e 3 ro м е}

В реализации принятой западными государствами так называемой народонаселеной стратегии уничтожения восстания (counterinsurgency, COIN) необычно существенную роль играет международное гуманитарное право (МГП), соблюдение и применение данного права является одним из гарантов достижения успеха у народонаселенных противоповстанческих операциях - получению поддержки населения, что позвоияет отсечь повстанцев с помощи, которая дается от данного населения и окончательно подавление восстания. Поэтому в противоповстанческих доктринах таких государств, как Великобритания и Соединенные штаты, а также в доктрине COIN, принятой НАTO, обязанность почета и соблюдение гуманитарного права, представляет необходимый фактор в каждом действии, в котором данное право может найти применение 
(напр. во время вооруженной акции против повстанцев или в случае их ловли). Каждая из этих доктрин заключает следовательно постановления, касающиеся принципов и норм МГП, хоть эти доктрины отдичаются между собой детальностью отнесений к МГП, не все те же вопросы, входящие в сферу регулирования данного права, были в доктринах затронуты.

Кдючевые слова: международное гуманитарное право, право вооруженных конфликтов, борьба с восстанием, противоповстанческие доктрины 